\title{
UNCONDITIONAL BASIC INCOME AS AN INSTRUMENT FOR REDUCING INCOME INEQUALITIES. THE CASE OF POLAND
}

\author{
Piotr MISZTAL \\ (Received: 1 November 2017; revision received: 20 March 2018; \\ accepted: 20 March 2018)
}

\begin{abstract}
Unconditional basic income (UBI) is the income allotted to all members of society individually, without the need to work. The right to this income and its level are unconditional and independent of the size and structure of households. In addition, the unconditional income is paid regardless of the income of citizens from other sources. The aim of this paper is to provide a theoretical and an empirical analysis of the UBI, with particular emphasis on the genesis and the effects of introducing this mechanism. The research was based on the analysis of economics literature and empirical results. In the empirical part, the effects of the UBI pilot program implemented in various high and low economically developed countries have been taken into account. In particular, the effects of the Family 500+ program introduced in Poland have been presented, which is widely identified with the UBI program.
\end{abstract}

JEL classification indices: D31, H53, I30

Keywords: unconditional basic income, income inequality, economic policy

Piotr Misztal, Associate Professor at the Faculty of Law, Administration and Management, Jan Kochanowski University in Kielce (UJK), Poland. E-mail: pmisztal@ujk.edu.pl 


\section{INTRODUCTION}

The advanced economies are witnessing a widespread replacement of human labour with machinery and equipment. Frey - Osborne (2017) pointed out that about $47 \%$ of jobs in the United States are exposed to computerisation. Similarly, a study published by the Committee of Economic Development of Australia (CEDA) indicated that $40 \%$ of Australian jobs will be at high risk of computerization or automatisation in the next 10-15 years (Don 2016).

In 2014, the Warsaw Institute for Economic Studies, an independent thinktank specialising in strategic consulting, economic and institutional analyses, published a report, "Does a robot take you to a job? Sectoral analysis of computerisation and robotisation of European labour markets". According to the report, over two decades, one third of the professions in Poland would be threatened with technological unemployment. The Scandinavian and the Benelux countries were identified as the least vulnerable to this threat. In Norway and Switzerland, the percentage of jobs threatened with automatisation is $17.5 \%$ and $18.7 \%$, respectively, while for Poland it is as high as $36.1 \%$. Moreover, there is a strong correlation between vulnerability to technological unemployment and the level of economic development of a given country. This is because some phenomena and processes in the richer developed countries have already taken place. In countries with lower GDP per capita, a higher share of people is at risk of mechanisation and computerisation.

As a result, there are growing concerns about the future of employment, social welfare and the financial stability of social security systems. In addition, tax systems that rely on income from workers may be subjected to severe pressure because the machines that replace human labour do not pay taxes or pay contributions to social security systems. Finally, technological change can lead to increase of income disparities in society and stronger polarisation between owners of capital and labour, especially for lower-skilled workers.

The Universal Declaration of Human Rights states that "everyone has the right to life, liberty and security" and "the right to a standard of living that guarantees the health and well-being of his and his family." In response to this statement, the concept of "basic income" was introduced, which should be an unconditional income, offered to all persons in all countries.

The aim of this paper is to analyse the theoretical and empirical aspects of the unconditional basic income, with particular emphasis on the origin and effects of introducing this mechanism. Our research based on literature in macroeconomics and economic policy, and statistical and descriptive methods based on data published by the Organisation for Economic Co-operation and Development and the World Bank. 


\section{THE ESSENCE OF UNCONDITIONAL BASIC INCOME}

There are three important forms of state-guaranteed, unearned incomes: unconditional basic income (UBI), negative income tax and wage supplement. UBI, called as "citizen income" or "demogrant", is an unconditional income granted to all members of the public individually, without the need for work, and regardless of individual's wealth. The right to income and the level of income are independent of the size and structure of households, and unconditional income is paid regardless of the income of citizens from other sources. If basic income reaches a level sufficient to meet basic needs, the basic income is said to be full, and if it is lower, it is a partial income (Fumagalli et al. 2014). The fundamental idea of introducing UBI is that all citizens, regardless of their individual income, receive a uniform amount of money from the state every month to meet their basic needs. As a result, all other state-provided social benefits, such as unemployment benefits or child benefits, are withdrawn. Such UBI would be largely financed by elimination of costs, which in some cases would have highly complex social benefits (including related administrative expenses).

UBI may take the form of a negative income tax (NIT). NIT occurs in conjunction with the existing income tax system of a progressive nature. A NIT leverages the mechanism by which tax revenues from people with incomes above the minimum are collected to provide financial assistance to people with incomes below that level. Hence, the taxable income of individual households is deducted from the basic income of their members. If the difference is positive, then the tax should be paid. If the difference is negative, the state pays to the household. The distribution of household incomes achieved with the UBI can be the same as the distribution of incomes with NIT. Despite the apparent similarity of the above mentioned mechanisms, NIT may be less costly. This is due to the fact that in the case of UBI there are two-way cash flows, one resulting from the payment of basic income and the other related to the payment of income tax. Moreover, in the case of a NIT there is one payment for households. On the other hand, UBI is characterised by a certain advantage over NIT, which results from the fact that each variant of the NIT needs to be supplemented by an instalment system before the final tax settlement is reached at the end of the fiscal year. In addition, despite the same distribution of income between households, in the case of UBI, the distribution of income within the household itself is more equal than with NIT. Finally, under the UBI program, beneficiaries receive a fixed income regardless of whether they earn additional incomes (e.g. from employment) or do not earn any income. Conversely, the NIT depends on the income earned by household members (Van Parijs 2000). 
Both UBI and NIT can generate similar outcomes but take different paths to get to that point. UBI gives money unconditionally but later takes it away for the rich, whereas NIT gives money only to the poor, not the rich. ${ }^{1}$ In the case of NIT, benefits are calculated according to the following equations:

$$
\begin{array}{lll}
B=G-T \times Y & \text { if } & 0 \leq Y \leq k \\
B=T \times(k-Y) & \text { if } & Y \geq k
\end{array}
$$

where:

$B$ - net benefit (with negative sign) or the tax paid (with positive sign),

$Y$ - gross income,

$G$ - maximum amount of NIT paid to individuals with zero-income,

$k$ - deduction,

$T-$ tax rate.

Benefits from UBI are calculated according to the equation presented below:

$$
B=g-T^{\prime} \times Y
$$

where:

$T^{\prime}-$ tax rate,

$g$ - fixed and universal level of benefit.

Assuming that $T=T$, it will be the equilibrium of benefits between the two motioned programs. In this situation, it will consider the disposable income equivalence condition between a deduction and a detraction.

Profits from NIT equal the area (OGE) in Figure 1. It decreases with income at a rate $T$ and it is equal to 0 when income $Y$ is equal to the deduction $k$. Over this threshold, taxpayers have to pay a positive tax, shown by the area (EMN).

In the case of UBI, individuals with gross income lower than $(\mathrm{OE})$ will receive positive benefits from the difference between this income $(\mathrm{Og})$ and taxes paid, measured by the vertical distance between the $45^{\circ}$ line and the piece $(\mathrm{gM})$. Taxpayers with an income higher than (OE) will pay a net tax. The net cost of the UBI program will be equal to the area (OKE).

The third form of guaranteed income is salary supplements, that is, wage supplements designed to provide additional income so that no worker earns less than a certain level of income. The government in this case guarantees coverage of the difference between what the individual has earned and the minimum state set (Tanner 2015).

1 Negative income tax is similar to giving someone 50 EUR for nothing. But unconditional basic income is similar to giving someone 100 EUR for 50 EUR from their next paycheck. In both cases the net benefit equals 50 EUR. 


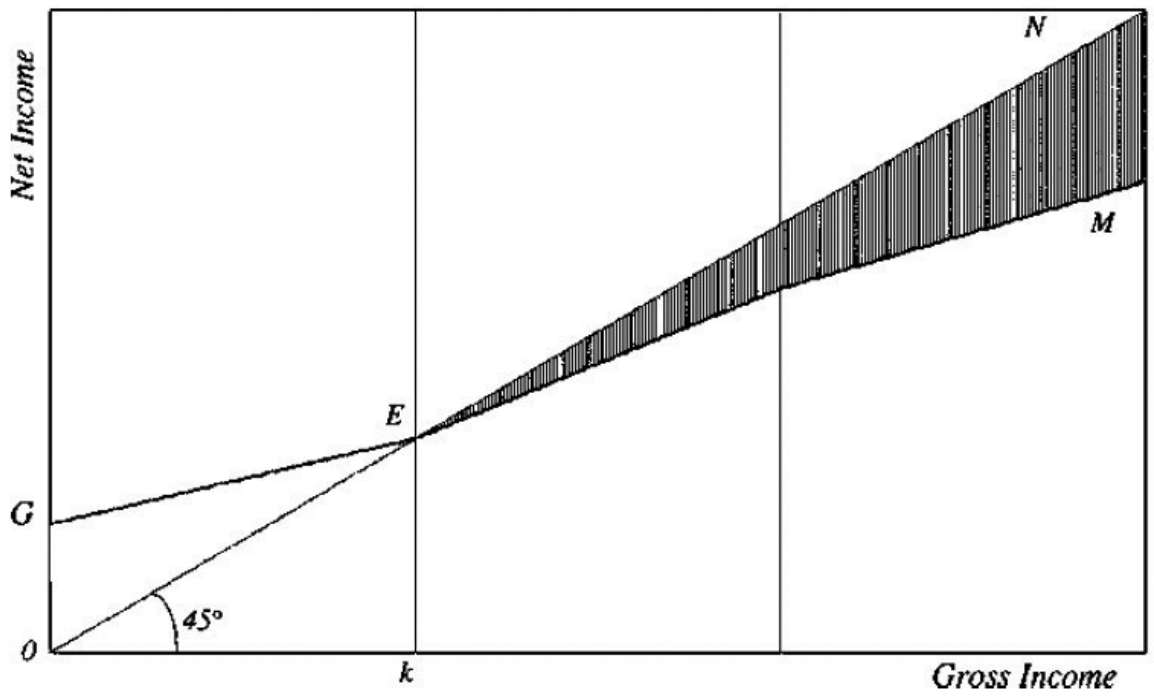

Figure 1. Benefits from negative income tax

Source: Tondani (2009).

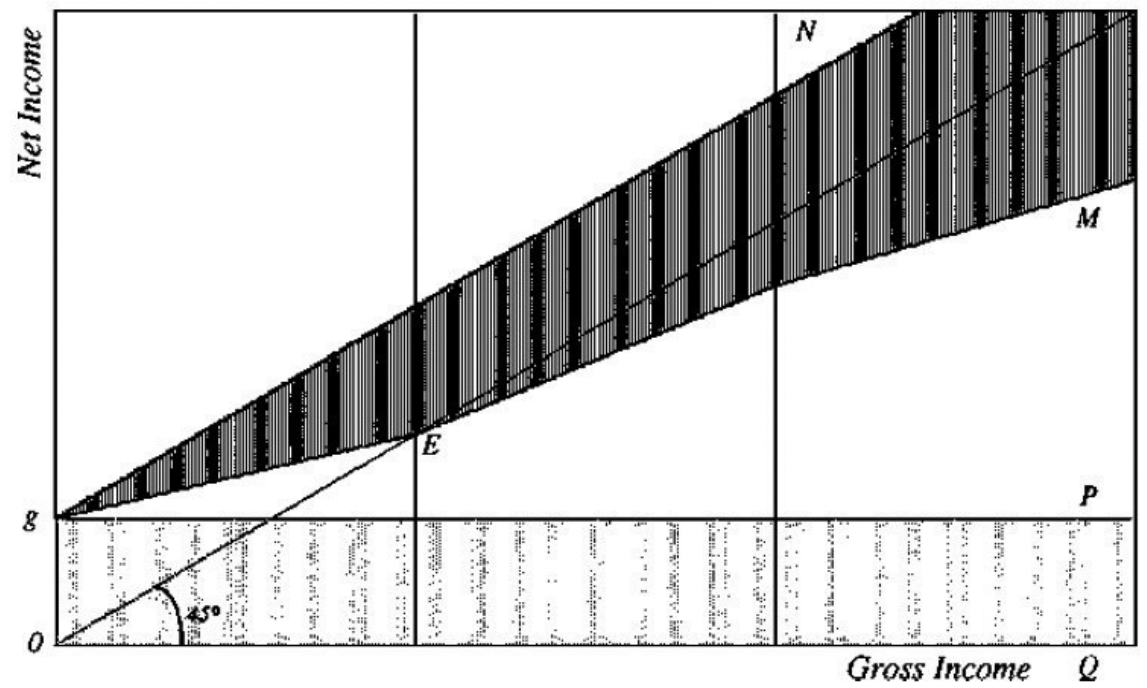

Figure 2. Benefits from unconditional basic income

Source: Tondani (2009). 
These concepts of income as well as the ways in which the income is distributed among citizens differ substantially, depending on the economic doctrine that we deal with. Namely, according to the classic (liberal) approach, the proponents of basic income postulate the idea of a "negative income tax". According to this doctrine, the functions of the state should be limited to the minimum necessary, by setting a negative progressive tax. People below the poverty line would not pay income taxes then, and the state would pay the necessary funds to meet each person's threshold. In this case, public services (schools, healthcare, etc.) would be paid, and the exception would be national justice and defence.

In turn, according to the doctrine of the social democrats, it is necessary to ensure the continuity of income for the unemployed or those whose income from work is too low. In this case, the guaranteed income should only be for those who are without a suitable source of income. Such redistribution of income is independent of the activity undertaken and continues until the benefit of the beneficiary falls below the poverty line. So this concept coincides with the idea of guaranteed pay.

According to the approach presented by some radical thinkers, the basic income should be universal, unconditional and indefinite. Such a benefit would not be discriminatory and would constitute a continuous benefit, independent of actual professional activity and providing a standard of living for every citizen of a given country or region.

\section{THE ORIGINS OF THE UNCONDITIONAL BASIC INCOME}

The idea of UBI dates back to 1796, when the English radical thinker, Thomas Spence (1982) put forward the first coherent and elaborate proposal to grant equal treatment to all residents without any precondition. These amounts were to be granted to all citizens equally and paid quarterly. These funds were to come from a part of the income earned by the whole community from the land lease.

In the $19^{\text {th }}$ century, the demand for introducing basic income was adopted by radical and socialist movements. The supporters of this concept included Charles Fourier (1845) and Joseph Charlier (1848) (Cunliffe - Erreygers 2001). Increasing popularity and recognition of the notion of basic income was obtained in the first half of the $20^{\text {th }}$ century. The main merit is attributed to the activities of Bertrand Russell and Dennis Milner, who put forward a proposal of universal income to help tackle poverty.

At the end of the 1960s and early 1970s, interests in the concept of UBI appeared again. In the 1972 presidential election in the United States, Nobel laureate James Tobin called on democratic candidate George McGovern to propose 
the idea of UBI while another Nobel Prize winner, Milton Friedman, proposed to republican candidate Richard Nixon to implement the concept of negative income tax (Fumagalli et al. 2014).

As proposed by Tobin, the UBI can be expressed in arithmetic form as $t=x+$ 25 , where $t$ is the average tax rate (in per cent of GDP) necessary to finance the planned basic income $(x)$, expressed as a percentage of GDP per capita. The justification for this expression is that the basic income payments must be financed in the long run, and $25 \%$ is the approximate share of the expenditure required to finance non-social public expenditure (health, education, public administration, public debt, military spending, etc.) (Kay 2017).

In a 1986 conference organised in Belgian Louvain-la-Neuve, the Basic Income European Network (BIEN) was created by the philosopher and economist Philippe Van Parijs. In 2004, the organisation changed its name to Basic Income Earth Network, transforming itself from a European network into a global organisation. In 1988, the first issue of the Basic Income Studies journal was published, devoted entirely to the detailed analysis of the basic income concept.

\section{Some examples}

In recent decades, many countries and regions within certain countries have implemented the idea of basic income in full or pilot form.

In 1976, the State of Alaska in the United States formed a Standing Fund to invest its revenue from the sale of crude oil in recognition that the mineral resources belonged to the Alaska residents (Fumagalli et al. 2014). Since 1982, dividends have been paid on a per-capita basis to all residents of the state. The only criterion for receiving the financial assistance was a requirement of a resident status for at least one year, with the intention of remaining resident in Alaska. The dividends were calculated on a yearly basis based on the Fund's five-year average investment performance. The largest dividend of $\$ 3269$ was paid in 2008 and included a one-time $\$ 1,200$ bonus to compensate residents for high fuel prices. In 2012, the dividend was $\$ 878$ per person or $\$ 3512$ for a family of four. Currently, the annual dividend is $\$ 2,000$ per capita and shows an upward trend every year.

This dividend played an important role in making Alaska one of the states with the lowest poverty rate in the United States and one of the smallest income inequalities. Although the individual dividend was relatively small, the overall impact on the economy was significant, as in 2009 the purchasing power of the Alaskan residents increased by $\$ 900$ million. These results were comparable to the creation of a new branch in the economy or the creation of 10,000 new jobs. 
At the same time, the impact of the dividend paid on the labour market was not observed.

Between 1968 and 1978, four guaranteed income experiments were conducted in other states (New Jersey, Seattle, Denver, North Carolina, Iowa, Gary, and Indiana). The tested system was in the form of NIT and not guaranteed basic income, due to the similarity of the two systems. The results of the experiment revealed that men and women receiving income reduced their working time by an average of $7 \%$ and $17 \%$, respectively. This was mainly due to the reduction in the working hours rather than the total absence of work. Monthly expenditures increased moderately with increasing incomes, and the structure of these expenditures did not changed substantially (Munnell 1986).

In 2008, a non-governmental organisation called ReCivitas launched a pilot project to pay basic income in the small town of Quatinga Velho located near Sao Paulo, Brazil. The project was financed by private donations and provided monthly unconditional income of $\$ 13.6$ per capita to 27 people. Over the next three years, the number of people receiving the payments increased to 100 . The monthly payment of unconditional income was well below the poverty line, but even the villagers who received this basic income showed an improvement in their ability to meet the basic needs. Researchers noted an improvement in the quality of nutrition among residents, with $25 \%$ of basic income being spent on food. There was improvement in health and living conditions, too (Pasma 2014).

In Greece from November 2015 to April 2016 the government experimented with a six-month pilot program providing flat cash grants to middle- and lowincome citizens in 30 municipalities. The program provided flat payments of $€ 200$ for a single person, plus an additional $€ 100$ per additional adult and $€ 50$ per child. Greek politicians suggest that the program could eventually be expanded nationwide.

The British government has also taken small steps in the direction of replacing traditional welfare benefits with cash payments. In 2013, the British government announced that it would consolidate six major welfare programs into a single cash grant. The benefits would be paid in a monthly lump sum. However, there have been significant implementation problems with the proposal, and it is not completed until the beginning of 2019.

\section{Opinions about introduction}

In January 2013, an annual signature collection procedure was launched under the European Citizens' Initiative for Basic Income. The aim of the initiative was to oblige the European Commission to encourage the Member States to cooperate 
in undertaking research on basic income as a tool to repair their social security systems. However, it did not succeed, as instead of the required million signatures there were only 285,000. Only six countries (Bulgaria, Slovenia, Croatia, Belgium, Estonia and the Netherlands) managed to gather the minimum number of signatures required, and the previously set target was reached only in Bulgaria. Since then the proponents of the basic income concept set up an organisation called Unconditional Basic Income Europe in 2014.

In 2016, a national referendum was held in Switzerland, which aimed at introducing a basic income. $77 \%$ of the Swiss population opposed the plan, and only $23 \%$ supported it. The basic income proposal was addressed not only to adults but also to children; that they would receive unconditional monthly income irrespective of their social and professional status. The monthly income paid by the state would have amounted to 2500 Swiss francs for adults and 625 Swiss francs for children. These figures reflected the high cost of living in Switzerland.

The most advanced experience with basic income can be attributed to Finland, where 2 thousand unemployed were paid benefits of EUR 560 per month in 2017 and 2018. In this case, the basic income did not eliminate additional benefits for citizens (e.g. housing benefit) and also did not lead to changes in taxes for people receiving basic income. So far, only the first year data were assessed, the 2018 figures are still awaiting for publication.

\section{THE EFFECTS OF THE INTRODUCTION OF AN UNCONDITIONAL BASIC INCOME}

The economics literature points to the measurable benefits of introducing UBI, as follows:

- UBI allows citizens the freedom to spend money in the way they want. In other words, basic income strengthens economic freedom at the individual level. This income provides the freedom to choose a particular type of activity instead of forcing people into unpleasant work to meet their daily needs.

- Basic income is a kind of unemployment insurance and can thus contribute to reducing poverty.

- Basic income leads to more equal distribution of income.

- The increase in income improves the bargaining power of citizens, as they no longer have to accept the offered working conditions.

- The unconditional income is easy to implement. Due to its universal character, there is no need to identify beneficiaries. It therefore excludes errors in 
the identification of planned beneficiaries, which is a common problem in targeted social programs.

- Due to the fact that each unit receives basic income, it promotes efficiency, reducing losses in government transfers. Moreover, the direct transfer of the unconditional income to citizens can contribute to curbing corruption in the country. Additionally, the benefits may result from the reduction of costs and time as a result of substituting the basic income of many social programs.

- Finally, transfers of basic income directly to bank accounts can increase the demand for financial services, which promotes the development of the financial market in the country.

On the other hand, opponents of the UBI concept point to the following disadvantages of this system:

- First of all, it has a risk of moral hazard. The consequence is the reduction of motivation to work and the consequent drop in labour supply.

- In addition, it is about fiscal costs and the risk of falling purchasing power of transfers received by citizens. Namely, the opponents of the unconditional income concept will find that after raising unconditional income, taxes rise in the country to finance growing government spending.

- Moreover, the increase in money supply in the country may cause an increase in inflation.

It is obvious that the impact of the basic income on the whole economy cannot be unequivocally defined, since the income affects the individual areas of economic life, and in some cases it is positive and in others negative (Sattelberger 2016).

The impact of introducing UBI on employers can be positive for jobs that stimulate the competitiveness among workers. Without working to ensure a specific level of living, individuals can develop and seek work that will offer them satisfaction and the ability to feel fulfilled. Increasing competition will attract more qualified people to the labour market, more willing to learn and develop, and thus will have a strong human resource development. By receiving unconditional income they are able to pursue their own continuous development by engaging in programs that will help them get the desired positions by being able to invest a portion of basic income into education without affecting the family budget.

In addition, the continued social protection and increased labour supply in the market will allow employers to lower wages. However, there is a high risk for employers offering jobs to people with lower qualifications. In this case, to fill vacancies, the employer will have to pay a higher salary. The rise in the wage fund will lead to higher prices, and the increase in prices will entail the need to increase UBI. 
The progressive income tax, which is currently in practice in most countries around the world, seems to be the best available source of funding UBI. The introduction of basic income must be accompanied by an organic or even a complete elimination of other forms of social assistance, such as unemployment benefits, pensions, social allowances, leaving only funds available for people with disabilities. In addition, the introduction of UBI may contribute to the reduction of state budget expenditure as a result of declining employment in the public sector. Further, the elimination of unemployment insurance premiums and social security contributions may lead to a reduction in fiscal pressure on the economy (Cercelaru 2016).

\section{UNCONDITIONAL BASIC INCOME IN THE LIGHT OF THE RESULTS FROM EMPIRICAL ANALYSIS}

The OECD (2017) published a report which stated that for most of the highincome countries, unconditional core income can actually increase poverty. Their model was based on a scenario in which all existing cash and tax benefits for people younger than 65 years are replaced by unconditional basic (or core) income in the 35 member countries. The analysis argues that governments in most Member States implement social support programs for the poor, while unconditional basic income will make it less precise in targeting the poor. The OECD has conducted a detailed analysis of the impact of UBI on four Member States: Finland, France, Italy and Great Britain. In three out of the four countries the hypothetical unconditional income would actually increase poverty by at least $1 \%$.

Jessen et al. (2015) conducted research on the potential effects of introducing an UBI in Germany at 800 euros per month for adults and 380 euros per month for people less than 18 years of age. These figures are close to the current level of guaranteed unemployment benefits and social assistance. The study assumes that this mechanism is financed from a $68.9 \%$ linear tax. Researchers have found that the reform would increase labour supply in the first decile of income distribution. This effect would be significant and would increase labour the supply of this group by $6.1 \%$. In addition, the introduction of the UBI would reduce labour supply in most of the remaining income decisions. And, in general, this UBI would reduce the total labour supply by $5.2 \%$. Utilizing the utilitarian social welfare function, the authors of the study have concluded that the overall social benefits to be achieved would be higher compared to the present situation. The result of the analysis has thus confirmed that the introduction of the UBI would be economically justified, it would increase motivation to work in poorer households, and would bring higher social benefits compared to the present system. 
In 2011, the United Nations Educational, Scientific and Cultural Organisation (UNESCO) completed a pilot project in partnership with SEWA (Self Employed Women's Association) in India to analyse the effectiveness of UBI among thousands of people living in the State of Madhya Pradesh. The study confirmed the increase in local economic activity that led to the emergence of micro-businesses, the creation of new jobs, and increasing purchases of technical equipment and livestock in the local community. In addition, people receiving UBI made significant improvements in respect of child nutrition, enrolment of children, health care and accommodation. It should also be noted that the increase in benefits for women was higher than for men (increasing financial autonomy for women), greater in the case of people with disabilities compared to healthy persons, and greater among the poorest than the wealthy people (Davala et al. 2014).

Hum and Simpson, referring to the experiments in the 1970s in Manitoba, Canada, acknowledged that employment reduction after introducing UBI was relatively small (about $1 \%$ for men, $3 \%$ for married women and $5 \%$ for unmarried women). The researchers noted that the introduction of UBI had a significant impact on the structure of households (Hum - Simpson 2001).

\section{UNCONDITIONAL BASIC INCOME IN POLAND}

The 500+ Family Program, introduced in Poland in 2016, could be described as a quasi-guaranteed income which is paid multi-children families, regardless of the income earned by the household. 500 PLN per month is paid by the state for the second and subsequent children. Low income families receive the support also for the first or only child, if they meet the criterion of average monthly net income of PLN 800 or PLN 1200 in case of raising a disabled child in the family. By the end of 2016, 3.8 million children were eligible for the support, representing 55\% of all children under the age of 18 . The program has dramatically improved the material conditions of these families, resulting in a reduction in the number of people benefiting from social assistance and nutritional support. With the program, total poverty has decreased by $48 \%$ and extreme poverty by $98 \%$ (Ministry of Family, Labour and Social Policy 2017).

Goraus - Inchauste (2016) estimated that poverty and inequality in Poland would fall as a result of the introduction of the Family 500+ program. Indirect taxes were also expected to increase, but the net effect on disposable income was estimated to be positive, with extreme poverty declining from 8.9 to 5.9 per cent relative to the situation in 2014.

The cost of the program is about 25.7 million PLN per year (1.5 per cent of GDP). When authors took into account the likely increase in Value Added Tax 


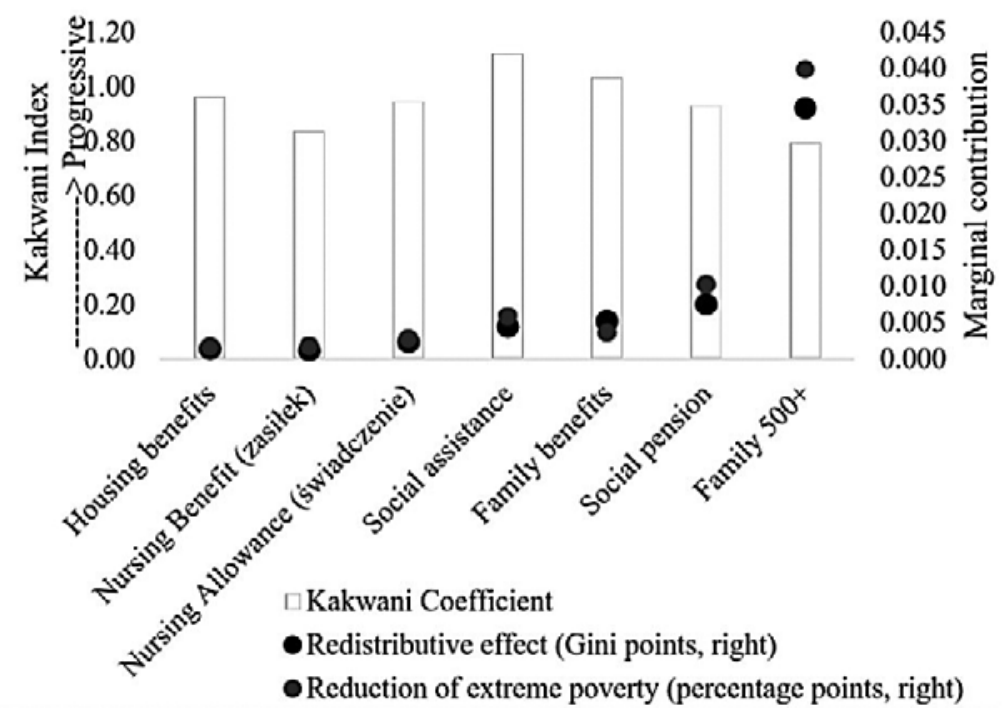

Figure 3. Progressivity and marginal contribution of the Family 500+ program

Source: Goraus - Inchauste (2016).

(VAT) and excise tax, the net cost of the program was estimated to be 22.2 million PLN per year (1.3 per cent of GDP). To compare the efficiency of the new program relative to other existing programs, mentioned in Figure 3, researchers calculated the change in poverty and extreme poverty per zloty spent for each program. They found that the change in poverty and inequality was lower for the Family 500+ program compared to social subsidies, social assistance, nursing allowances and housing benefits, because these were more targeted. Further, the Family $500+$ program was more efficient than spending on nursing benefits and family benefits (Goraus - Inchauste 2016).

In addition to the 500+ Family Program, the government is going to increase next year the tax-free allowance for PIT from PLN 3,000 to PLN 8,000 in 2019. In relation to this, researchers made simulations for the following two scenarios, tax-free allowance increases to PLN 5,000, or to PLN 8,000. Research also showed the impacts of these alternative reforms in combination with the Family $500+$ Program on poverty and inequality, along with the estimated fiscal cost of these measures. The results indicate that an increase in the value of the taxfree allowance leads to more progressive PIT and health insurance contributions, causing more progressive and redistributive direct tax system. The increase in disposable income as a result of the tax-free allowance is assumed to slightly increase the burden of indirect taxes. However, the net effect is a net gain for all the households (Goraus - Inchauste 2016). 


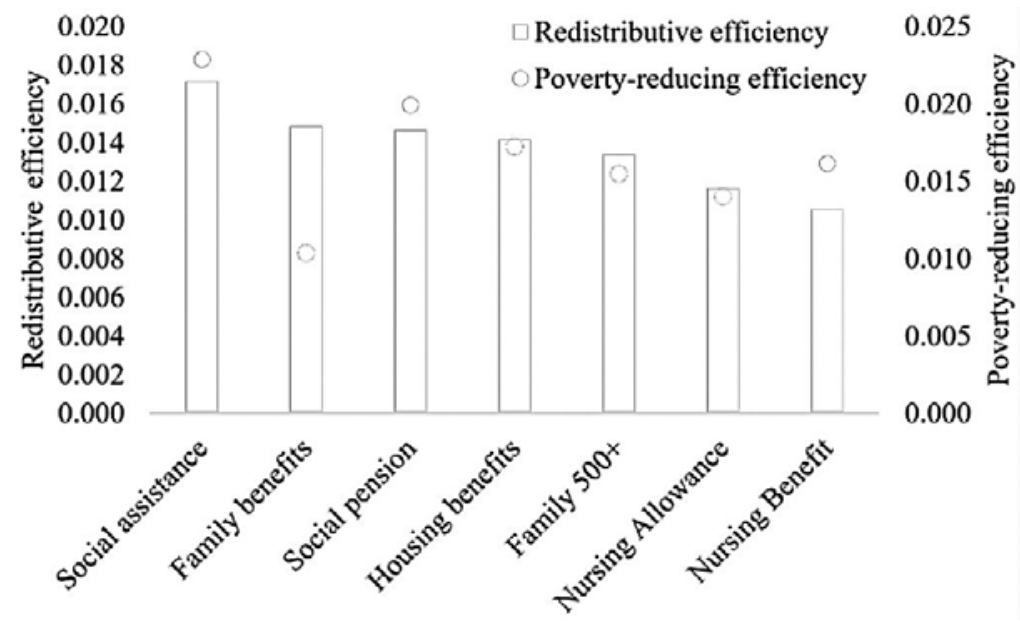

Figure 4. Efficiency of social spending

Source: Goraus - Inchauste (2016).

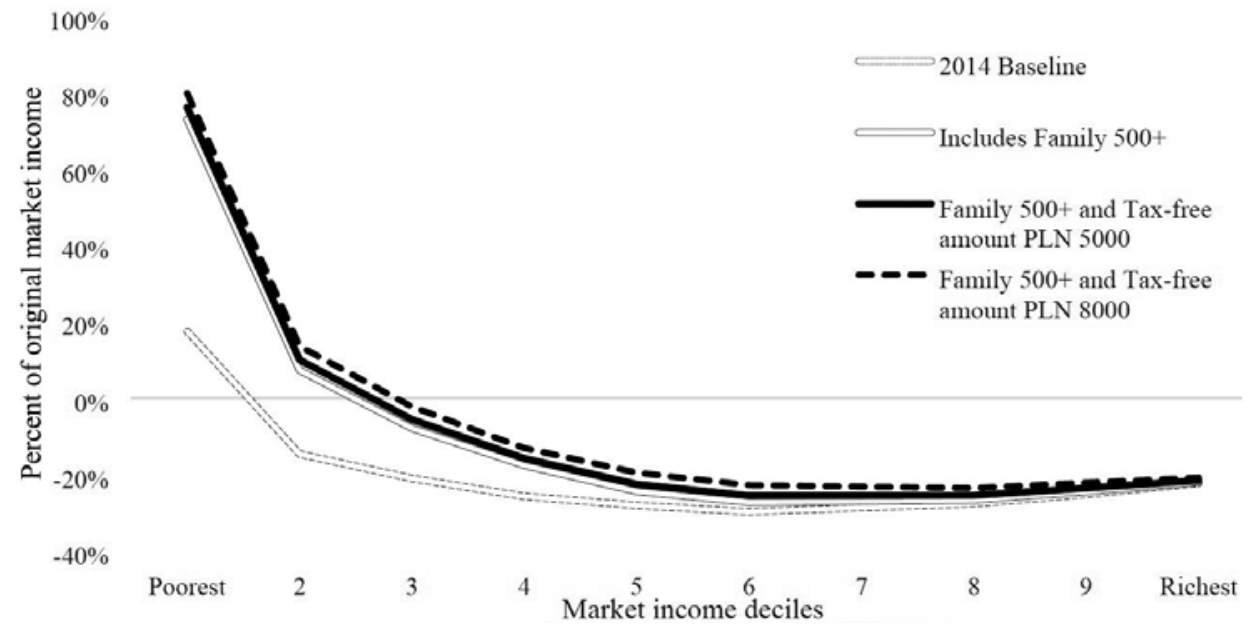

Figure 5. Financial position of households under alternative reforms in Poland

Source: Goraus - Inchauste (2016).

According to Figure 5, households in the second decile will receive more in transfers than they pay into the system through direct and indirect taxes and contributions largely due to the Family 500+ Program, although all households will have a net gain. Moreover, it seems important to assess how these initiatives will be financed in the future, and the potential distributional impact of measures needed to ensure that the government is able to keep its budget deficit rule. 


\section{CONCLUSION}

Supporters of the UBI program argue that it is a very simple and transparent transfer system that drastically reduces the possibility of abuse compared to other systems commonly used today. In addition, the introduction of basic income reduces the stigmatisation of applicants. At the same time, the supporters say that they create a more egalitarian society and open up possibilities for individual self-realisation. Moreover, basic income supporters argue that technological development constantly replaces manual labour. This means that a small group of people with high wages will face a growing number of unemployed. The UBI will then ensure the necessary social balance.

The opponents of the UBI program claim that the belief in equal distribution of basic income is only wishful thinking and it can never become a reality. In addition, unconditional income raises the risk of abuse (moral hazard), because the basic income would significantly reduce the willingness to take up employment and thus lead to a decrease in employment. This would reduce the driving forces of the market economy. In addition, the introduction of basic income would result in the loss of other social benefits and thus the need for self-financing of social needs.

The UBI is, in fact, a radical change in the present welfare system, equitable, liberal and it treats all citizens equally. People with higher incomes pay more taxes than people with lower incomes in absolute and relative terms. The minimum living income is guaranteed to everyone, and people without income receive net transfers. Although the concept of unconditional guaranteed income is neither perfect nor cheap to implement, it seems reasonable to at least consider the radical change of the current social assistance system. At times, it turns out that the risk of radical change is less than the risk of continuation of the existing system, as the current social system can exacerbate social and political pressure as a result of increasing polarization of society.

\section{REFERENCES}

Cercelaru, O. V. (2016): Unconditional Basic Income - Impact on the Economy. Annals of the Constantin Brâncuşi University of Targu Jiu, Economy Series, No. 3.

Chéron, A. (2002): Allocation vs. Universal Unemployment Allowance. Quantitative Evaluation in a Matching Model. Economic Review - Persee, 53(5): 951-964.

Cunliffe, J. - Erreygers, G. (2001): The Enigmatic Legacy of Charles Fourier: Joseph Charlier and Basic Income. History of Political Economy, 33(3): 459-484.

Davala, S. - Jhabvala, R. A. - Standing, G. - Mehta, S. K. (2015): Basic Income. A Transformative Policy for India. London - New York: Bloomsburs Academic.

Dickinson, H. T. (ed.) (1982): The Political Works of Thomas Spence. Newcastle Upon Tyne: Avero. 
Don, A. (2016): Basic Income: A Radical Idea Enters the Mainstream. Parliament of Australia. Research Paper Series, November 18.

Frey, C. B. - Osborne, M. A. (2017): The Future of Employment: How Susceptible are Jobs to Computerisation? Technological Forecasting and Social Change, 114C: 254-280.

Fumagalli, A. - Lucarelli, S. - Maciejewska, G. - Marczewski, P. - Mika, B. - Moll, Ł. - Szarfenberg, R. - Szlinder, M. - Ślosarski, B. (2014): Unconditional Basic Income. Theoretical Practice, 2(12): 1-22.

Goraus, K. M. - Inchauste, M. G. (2016): The Distributional Impact of Taxes and Transfers in Poland. Policy Research Working Paper, No. 7787, World Bank.

Hum, D. - Simpson, W. (2001): A Guaranteed Annual Income? Mincom from to the Millennium. Policy Options, 22(1): 78-82.

Jessen, R. - Rostam-Afschar, D. - Steiner, V. (2015): Getting the Poor to Work: Three Welfare Increasing Reforms for a Busy Germany. Discussion Papers, No. 22, Freie Universität Berlin, School of Business \& Economics.

Kay, J. (2017): The Basics of Basic Income. Intereconomics, 52(2): 69-74.

Lehmann, E. (2003): Evaluation of the Implementation of a Universal Allowance System in the Presence of Heterogeneous Qualifications: The Institutional Role of the Minimum Wage. Économie \& Prevision, 157(1): 31-50.

Munnell, A. (1986): Lessons from the Income Maintenance Experiments: An Overview. Conference Series, No. 30, Federal Reserve Bank of Boston.

OECD (2017): Basic Income as a Policy Option: Can it Add up? ELS Policy Brief, 24 May.

Pasma, C. (2014): Basic Income Programs and Pilots. Basic Income Canada Network, February 3.

Sattelberger, J. (2016): Unconditional Basic Income: An Instrument for Reducing Inequality? KfW Development Research, No. 39. Frankfurt am Main.

Tanner, M. D. (2015): The Pros and Cons of a Guaranteed National Income. Policy Analysis, No. 773, Cato Institute.

Tondani, D. (2009): Universal Basic Income and Negative Income Tax: Two Different Ways of Thinking Redistribution. The Journal of Socio-Economics, 38(2): 246-255.

Universal Basic Income (UBI): Everything You Need to Know. http://www.clearias.com/universal Van Parijs, P. (2000): A Basic Income for All. Boston Review, 25 (October-November): 473-511.

Warsaw Institute for Economic Studies (2014): Does a Robot Take You to a Job? Sectoral Analysis of Computerization and Robotization of European Labor Markets. 


\section{ANNEX}

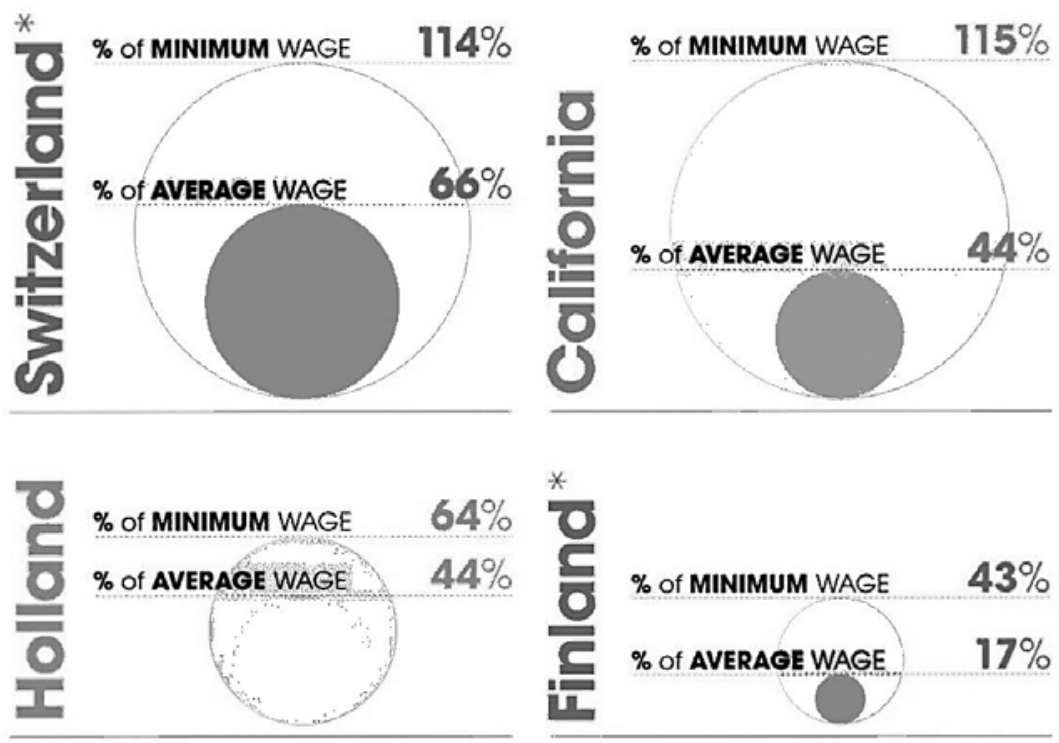

"Switzerland and Finland do not hove statulory minimum woges. These fgures are based on collective bargaining agreements.

Proposed basic income in selected countries

Source: https://apolitical.co 